\title{
Flavohaemoglobin HmpX: a new pathogenicity determinant in Erwinia chrysanthemi strain 3937
}

\author{
S. Favey, ${ }^{1}$ G. Labesse, ${ }^{1,2}$ V. Vouille ${ }^{1}$ and M. Boccara ${ }^{1}$ \\ Author for correspondence: M. Boccara. Tel: +331440816 98. Fax: +33144081700. \\ e-mail: Boccara@inapv.inapg.inta.fr
}

1 Laboratoire de pathologie végétale, INRA, INA P/G, 16 rue Claude Bernard, 75005 Paris, France

2 Département des macromolécules biologiques, Laboratoire de MinéralogieCristallographie, Universités Paris VI and VII, CNRS URA 09, 4 place Jussieu, 75252 Paris cedex 05, France

\begin{abstract}
Unlike wild-type Erwinia chrysanthemi strain 3937, which fully macerates inoculated Saintpaulia plants, HmpX- mutants produce necrotic lesions or no symptoms. The $h m p X$ gene was sequenced and the corresponding protein sequence analysed. We show that HmpX belongs to a family of flavohaemoproteins (HMP), previously identified in two yeasts and in Escherichia coli. Comparisons of protein sequences at the secondary structure level by hydrophobic cluster analysis have shown that HmpX possesses two functional regions, a haemoglobin domain in its $\mathbf{N}$-terminal part and a flavin reductase domain in its C-terminal part. In an HmpX- strain, the synthesis of pectate lyases, which are pathogenicity determinants in $E$. chrysanthemi, was reduced in conditions of low oxygen tension. Using gus fusion in $h m p X$, it was shown that hmpX transcription was induced in coculture with tobacco cells. A putative function for $\mathrm{HmpX}$ is discussed.
\end{abstract}

Keywords: anaerobiosis, bacterial haemoglobin, Erwinia cbrysanthemi, HMP, pectate lyase

\section{INTRODUCTION}

Erwinia cbrysanthemi is an enterobacterium which causes soft rot disease on a wide range of plants. This pathogen causes maceration of parenchymatous tissues by degrading the middle lamella and the primary cell wall through the action of depolymerizing enzymes, pectinases, endoglucanases and proteases. Among the pectinases produced in vitro, E. chrysanthemi strain 3937 secretes five pectate lyase (PL) isozymes (PLa to PLe; Bertheau et al., 1984). The five pel genes are organized in two clusters: pelB, $C$ encoding the neutral PL and pel $A, D, E$ encoding the acidic and basic PL (Kotoujansky et al., 1985). Strains with single mutations in genes encoding pectinases have been constructed and their pathogenicity on axenically grown plants (Saintpaulia ionantba, the South African violet) has been studied. The results have shown that several pectinolytic enzymes are involved in systemic infection of the host plant (Boccara et al., 1988). For example, a mutant unable to produce its five PLs is still

Abbreviations: a.u., arbitrary unit; DHPR, dihydropteridine reductase; Gus, $\beta$-glucuronidase; HCA, hydrophobic cluster analysis; HMP, flavohaemoprotein.

The EMBL accession number for the sequence reported in this paper is X75893. able to produce localized maceration but the infection does not progress to destroy the whole plant (Beaulieu $e t$ al., 1993). Therefore the PLs of E. chrysanthemi 3937 detected in vitro do not appear to be involved in the early events of infection.

In the search for bacterial functions involved in early steps of plant infection, several groups have isolated mutants unable to multiply in the host plant and unable to induce the hypersensitive response on non-host plants (for a review, see Willis et al., 1991). In phytopathogenic bacteria, including enterobacteria such as E. chrysanthemi (Bauer et al., 1994), a locus composed of a large number of genes named brp (hypersensitive response and pathogenicity) has been defined. The Hrp proteins probably encode a secretion apparatus for pathogenicity factors (Van Gijsegem et al., 1993). The function of these factors could be to cause release from the plant of the carbon and/or nitrogen sources necessary for bacterial growth within intercellular spaces.

Other environmental factors such as the availability of iron (Expert \& Gill, 1992) or oxygen tension (Billing, 1987) have been shown to be of great importance in the early steps of infection by plant pathogenic bacteria. For example, conditions that reduce oxygen tension in potato tubers, such as a film of surface water, make potatoes 
more susceptible to Erwinia carotovora (De Boer \& Kelman, 1978), suggesting that oxygen availability may be an important determinant in soft rot pathogenesis.

To find new pathogenicity factors we systematically mutated the region located in the vicinity of the pel genes. We found a cluster of mutations close to the pel $A, D, E$ region of strain 3937 (Reverchon et al., 1986), affecting the pathogenicity of E. chrysanthemi on Saintpaulia plants. In this paper, we present the sequence of the gene corresponding to the mutated region, which we have named $b m p X$, and we discuss the structure-function relationship according to the homologies shared by the encoded protein and families of related flavoenzymes. We show that this protein is important for $\mathrm{PL}$ production in a microaerobic environment.

\section{METHODS}

Bacterial strains, plasmids, media and growth conditions. Bacterial strains and plasmids are listed in Table 1. Escherichia coli strains were grown in Luria broth medium (Miller, 1972) at $37^{\circ} \mathrm{C}$. E. chrysantbemi strains were grown with vigorous shaking at $30{ }^{\circ} \mathrm{C}$ in M9 synthetic medium (Miller, 1972), plus $0.5 \%$ glycerol. Aerobic cultures were grown in Erlenmeyer flasks ten times larger than the volume of the culture medium. Microaerobic conditions were obtained by covering the cultures grown in tubes $(18 \times 160 \mathrm{~mm})$ in the same medium with $2 \mathrm{ml}$ vaseline and maintaining them without shaking at $30^{\circ} \mathrm{C}$ for $3 \mathrm{~d}$. Antibiotics were used at the following concentrations: ampicillin (Ap), $50 \mu \mathrm{g} \mathrm{ml}^{-1}$; chloramphenicol (Cm), $15 \mu \mathrm{g} \mathrm{ml}^{-1}$; and kanamycin $(\mathrm{Km}), 25 \mu \mathrm{g} \mathrm{ml}{ }^{-1}$.

Genetic manipulations. Plasmid pB413 was introduced into POII1734 or POIIPR13 dilysogenic strains to obtain mini-Mu (MudII1734 and dMudPR13) insertions (Catilho et al., 1984). The $\mathrm{Mu}$ prophages were thermo-induced. The resulting lysate was used to infect strain M8820, from which $\mathrm{Cm}^{\mathrm{r}}$ or $\mathrm{Km}^{\mathrm{r}}$ transductants were selected.

To marker exchange the mutated $b m p X$ gene with the $E$. chrysanthemi chromosomal allele, E. chrysanthem $i$ was first transformed with plasmid harbouring a mini-Mu insertion in $b m p X$ by the conventional calcium chloride method (Maniatis et al., 1982). Plasmid destabilization was obtained in low-phosphate medium (Roeder \& Collmer, 1985), and mutants growing on chloramphenicol or kanamycin but not on ampicillin were selected.

DNA manipulations. Standard molecular techniques were used, according to Ausubel et al. (1987) and Maniatis et al. (1982).

DNA sequencing was performed by the dideoxy chain-termination method of Sanger et al. (1977) using the Sequenase kit (United States Biochemical Corporation). The $1.5 \mathrm{~kb}$ DraI fragment containing $b m p X$ (Fig. 1) was hydrolysed by Sau3A or TaqI and subcloned into pUBS3. Sequence was obtained from primer sites in the vector and using synthetic oligonucleotides (Unité de Chimie organique, Institut Pasteur, Paris). Computer-

Table 1. Bacterial strains, bacteriophages and plasmids

\begin{tabular}{|c|c|c|}
\hline $\begin{array}{l}\text { Strain, bacteriophage } \\
\text { or plasmid }\end{array}$ & Relevant characteristics & Reference \\
\hline \multicolumn{3}{|l|}{ Escherichia coli } \\
\hline POII1734 & $\begin{array}{l}\text { F araD139 ara::(Mucts62)3 } \Delta(\text { lac }) \text { X74 galU } \\
\text { galK rpsL with MudII1734 }\end{array}$ & Castilho et al. (1984) \\
\hline POIIPR13 & $\begin{array}{l}\operatorname{rec} A 1 \text { end } A 1 \text { gyr-196 } \mathrm{Thi}^{-} \text {hsdR } 17 \text { supE44 } \\
\operatorname{rel} A 1 \Delta(\text { lac-pro } A B) \text { with } \mathrm{dMudPR} 13 \text { and } \\
\text { Mucts62 }\end{array}$ & Reyes et al. (1987) \\
\hline M8820 & $\begin{array}{l}\mathrm{F}^{-} \text {araD139 } \Delta(\text { ara-leu }) 7697 r p s L \\
\Delta(\text { pro } A B \text {-argF-lacIPOZY } A) \mathrm{XIII}\end{array}$ & Castilho et al. (1984) \\
\hline AR 1062 & Strain which generates minicells & \\
\hline DH5 $\alpha$ & Strain for propagating plasmids & \\
\hline \multicolumn{3}{|l|}{ Erwinia chrysanthemi } \\
\hline 3937 & Wild-type, isolated from Saintpaulia & Our collection \\
\hline PMV4125, PMV4127 & $b m p X:: \mathrm{dMudPR} 13$ derivatives of 3937 & This study \\
\hline PMV4128 & $b m p X::$ MudII1734 derivative of 3937 & This study \\
\hline $\mathrm{X} 8$ & $b m p X:: g u s \mathrm{Km}$ (transcriptional fusion) & This study \\
\hline $\mathrm{X} 2$ & $\begin{array}{l}h m p X:: g u s \mathrm{Km} \text { (cassette in the reverse } \\
\text { orientation) }\end{array}$ & This study \\
\hline \multicolumn{3}{|l|}{ Bacteriophages } \\
\hline MudII1734 & $\mathrm{Km}^{\mathrm{r}} \mathrm{Mu}$ derivative & Castilho et al. (1984) \\
\hline dMudPR13 & $\mathrm{Cm}^{\mathrm{r}} \mathrm{Mu}$ derivative & Reyes et al. (1987) \\
\hline \multicolumn{3}{|l|}{ Plasmids } \\
\hline pB413 & $\mathrm{Ap} / p e l A^{+} b m p X^{+}$derivative of $\mathrm{pUC} 9$ & Reverchon et al. (1986) \\
\hline p0165 & pB413 hydrolysed by EcoRI and religated & This study \\
\hline pUBS3 & $\begin{array}{l}\text { pUC derivative containing PBLUESCRIPT } \\
\text { polylinker }\end{array}$ & Murphy \& Kavanagh (1988) \\
\hline p19014 & Plasmid harbouring uid $A-\mathrm{Km}$ cassettes & Bardonnet \& Bianco (1992) \\
\hline
\end{tabular}


assisted analysis of the sequences was carried out using programs developed by the University of Wisconsin Genetics Computer Group (Devereux et al., 1984).

Minicell isolation and protein analysis. Minicells were isolated, labelled with $\left[{ }^{35} \mathrm{~S}\right]$ methionine (Amersham) as described by Rambach \& Hogness (1977), and their protein content analysed on a $12 \%(\mathrm{w} / \mathrm{v})$ SDS-polyacrylamide gel. Proteins were stained with Coomassie blue, and labelling was visualized by autoradiography, using Kodak X-OMAT AR films.

Protein sequence analysis. The deduced amino acid sequence of HmpX was compared to sequences from the SWISSPROT data bank (February 1994) with the FASTA program (Pearson \& Lipman, 1988), using the matrices of Dayhoff et al. (1978) and Risler $e$ t al. (1988). BLAST searches were performed to screen the GenPept databank (release no. 83) using the network service of the NCBI (Altschul et al., 1990). Pairwise and multiple alignments were determined by hydrophobic cluster analysis (HCA) as described in the original papers (Gaboriaud et al., 1987; Woodcock et al., 1992).

Enzyme activities in vitro. PL assays were performed on supernatants of cells grown to late exponential phase in M9 minimal medium plus $0.5 \%$ glycerol. PL activity was determined by monitoring the appearance of unsaturated products from polygalacturonate (Sigma), absorbing at $235 \mathrm{~nm}$ (Moran $e t$ al., 1968), in $0.1 \mathrm{M}$ Tris/ $\mathrm{HCl} \mathrm{pH} 8.6,5 \times 10^{-4} \mathrm{M} \mathrm{CaCl}_{2}$. PL specific activity was expressed as $\mu \mathrm{mol}$ unsaturated products liberated $\min ^{-1}$ ( $\mathrm{mg}$ bacterial dry weight $)^{-1}$.

Dihydropteridine reductase activity was assayed as described by Vasudevan et al. (1988).

$\beta$-Glucuronidase (Gus) activity was measured by following the degradation of PNPU ( $p$-nitrophenyl $\beta$-D-glucuronide) into $p$ nitrophenol, which absorbs at $405 \mathrm{~nm}$ (Bardonnet \& Blanco, 1992). Specific activity is expressed as nmol product liberated $\min ^{-1}$ per $10^{9}$ bacteria.

Construction of the hmpX::gus fusion. We used the gus-Km cassettes described by Bardonnet \& Blanco (1992), in which the gus gene is deleted of its own promoter region but conserves its Shine-Dalgarno sequence. The cassette obtained by SmaI digestion was ligated to the Klenow filled-in XmaIII site of $b m p X$. This gives rise to gus insertion in the orientation of transcription ( $\mathrm{pX} 8)$ and in the reverse orientation (pX2). The gus insertions were then introduced into the E. chrysanthemi chromosome by marker exchange recombination, generating strains X2 and X8, respectively.

Pathogenicity test. Pathogenicity tests were performed on Saintpaulia ionantha cultivar 'Blue Rhapsody'. Leaf parenchyma was inoculated with $100 \mu \mathrm{l}$ bacterial suspension in $0.9 \% \mathrm{NaCl}$ $\left(10^{8}\right.$ c.f.u. $\left.\mathrm{ml}^{-1}\right)$. After inoculation the plants were placed at $28^{\circ} \mathrm{C}$ under saturating humidity. The results were recorded daily for $15 \mathrm{~d}$ to give sufficient time for the development of symptoms. The inoculations were repeated three times.

Measure of enzyme activities in planta. To study PL activity in planta, leaf intercellular space was infiltrated in vacuo with bacteria $\left(10^{8}\right.$ c.f.u. $\left.\mathrm{ml}^{-1}\right)$. Infiltrated leaves were kept for $24 \mathrm{~h}$ at $30^{\circ} \mathrm{C}$ and then centrifuged as described by De Witt \& Spikman (1982). The intercellular fluid was used for PL assay and for bacterial enumeration by dilution plating.

Cell suspension cultures of Nicotiana tabacum cultivar Wisconsin clone 19-3 were grown in a slightly modified Murashige and Skoog medium, as described by Gregorini \& Laloue (1980), on a rotary shaker $\left(150\right.$ r.p.m.) in a growth chamber at $25^{\circ} \mathrm{C}$ under constant white light $(1500 \mathrm{~lx})$. Exponentially growing tobacco cells $\left(10 \mathrm{ml}, 4 \mathrm{~d}\right.$ after subculture) were mixed with $3 \times 10^{8}$ bacteria in the late exponential phase. After $24 \mathrm{~h}$ the plant cells were separated by filtration and bacteria collected by centrifugation for Gus activity assays and bacterial cell counting.

\section{RESULTS AND DISCUSSION}

\section{Pathogenicity of $h m p X$ mutant strains}

Plasmid pB413, which contains a $5.4 \mathrm{kbp}$ insert, was mutated in Escherichia coli by insertion of the mini-Mu transposable elements dMudPR13 and MudII1734. Three insertions (0163, 238 and 239, Fig. 1) were mapped 5' to the pel $A$ gene and were shown by restriction enzyme analysis to be clustered on a $500 \mathrm{bp}$ region. These insertions were exchanged with the E. chrysanthemi 3937 chromosomal allele, generating strains PMV4125, PMV4127 and PMV4128, respectively. The pathogenicity of these strains on Saintpaulia plants was compared with that of the wild-type strain 3937. When the wild-type strain was inoculated to Saintpaulia plants, a translucent spot was visible at the inoculation site after $24 \mathrm{~h}$. A week later, maceration had spread to the whole leaf and after two weeks the whole plant was diseased. In contrast, plants inoculated with strain PMV4125, PMV4127 or PMV4128 exhibited no symptoms, or only necrotic spots at the inoculation site, and necrosis did not spread over the two weeks of observation. This result, which is different from that observed with a pel $A$ mutant (localized maceration; Boccara et al., 1988) prompted us to sequence the mutated region.

\section{Nucleotide sequence of $h m p X$}

The nucleotide sequence of the $b m p X$ gene was determined (Fig. 2). We identified a 1185 bp open reading frame, coding for a protein of 395 residues with a calculated molecular mass of $44230 \mathrm{Da}$. Analysis of the region upstream of the coding sequence revealed the presence of a putative promoter similar to the consensus sequence promoter of $E$. coli. Furthermore, the presumed ATG translational start codon located at base 242 is favourably positioned behind a Shine-Dalgarno sequence. Downstream of the putative $b m p X$ stop codon TAA, a region similar to a bidirectional rho-independent transcription terminator in $E$. coli was detected. No

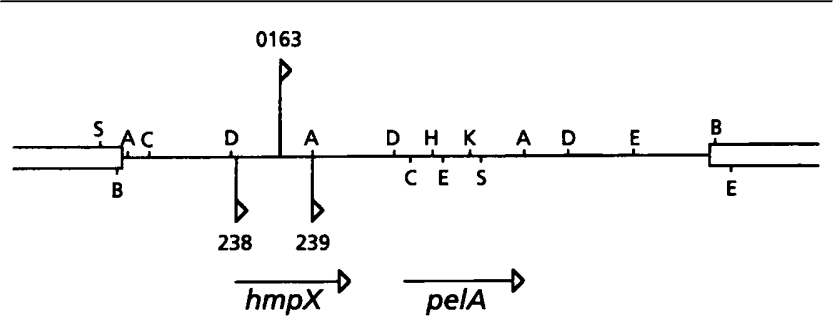

$1 \mathrm{~kb}$

Fig. 1. Restriction map of the fragment in the pUC9 vector (pB413) containing the $h m p X$ gene. The locations of the insertions are indicated by flags. Restriction enzymes: $A, A c c l$; B, Bglll/BamHI; C, Clal; D, Dral; E, EcoRI; H, Hpal; K, Kpnl; S, Sall. 
1 TGGGCTGACAGAGGTTTTACGCMACGATTAGCTACAGGCTACGCMAGCTTTACGTCTTTCCGGGATTAGCCATTCCGGCTGATTTTT

91 TCTCATCCTCAACCTGCATTTITTCATACGCCTTTCCCCCTGATTCGTTGCCCCGCCCCTACCCCAGACCATCACCGGGGATTTACAGC

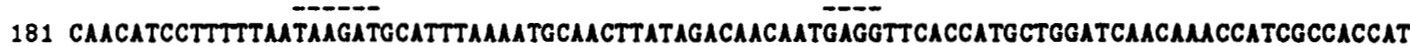
SD MetLeulspGInGInThrIleAlaThrII

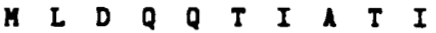

271 CAAATCCACCATTCCTCTGCTGGCCGMACCGTTCGGCGTTGACCGCTCACTTTTATCAGCGGATGTTCCACCATAACCCGGMCTGM

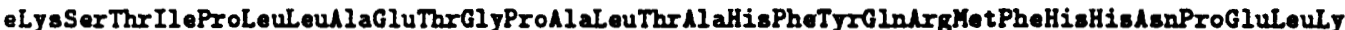

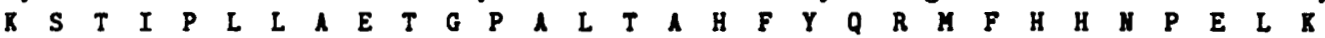

361 AGATATCTTCATATGAGTATCAGCGTMTGGCGACCAGCGCGMGCGGTGTTCAATGCCATTTGCGCCTACGCGACGCATATCGAMA shapIlePhedsnHetSerdsnGInhrghsnGl jhspGInhrgGludlaValPhedsndlaIleCjsAlaTjrAlaThrHisIleGIuds

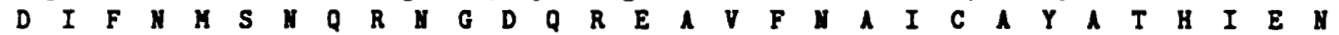

451 CCTGCCGGCGTTGCTGCCCGCGTAGM CGTATCGCGCAMAGCATGCCAGCTTCAATATTCAGCCGGAACAGTATCAGATAGTGGTAC nleuProdlaLeuLeuProllaValGluArgIleAlaGlnLysHisAlaSerPhedsnIleGlnProGluGlnTyrGinIleValgly Th $\begin{array}{llllllllllllllllllllllllllllll}L & P & A & L & L & P & A & V & E & R & I & A & Q & I & H & A & S & F & \text { I } & I & Q & P & E & Q & Y & Q & I & V & G & T\end{array}$

541 TCACCTGCTGGCAACGTGGAAGAATCTTCCAGCCCGGTCAGGCGGTGCTGGATGCCTGGGCAACGCTACGGCGTGCTGGCGMTGT

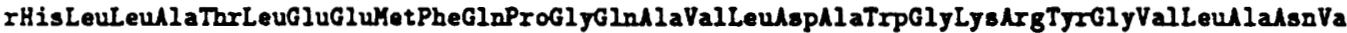
$\begin{array}{lllllllllllllllllllllllllllllll}H & L & L & A & T & L & E & E & M & F & Q & P & G & Q & A & V & L & D & A & V & G & K & R & Y & G & V & L & A & N & V\end{array}$

631 GTTTATCCAGCGGGAAACGACATTTATCAGCAMACGCCGGACMM CGGCGGCTGGCATGGCATCCGGCCGTTTCGCATTGTGGCGAA

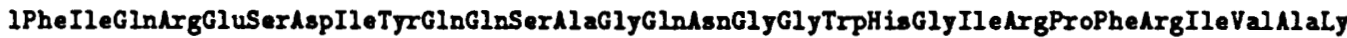
$\begin{array}{llllllllllllllllllllllllllllllll}F & I & Q & R & E & S & D & I & Y & Q & Q & S & A & G & Q & H & G & G & W & H & G & I & R & P & F & R & I & V & A & X\end{array}$

721 ACAGCCCCAGAGCAGCCTGATCACCAGCTTCACGCTGGACCGGTGGATGGCGGCCCGATCGCCGCATTCCGTCCCGGCCAGTATCTGGC sGlnProGlnSerSerLeuIleThrSerPhe ThrLeuG I uProValAspGlyGl yProIleAlaAl aPheArgProGl yGlnTyrLeuAl $\begin{array}{lllllllllllllllllllllllllllllll}Q & P & Q & S & S & L & I & T & S & F & T & L & E & P & V & D & G & G & P & I & A & A & F & R & P & G & Q & Y & L & A\end{array}$

811 GGTCTACATCCGCGATAAGCCTTTGMTATCAGGAGATTGTCAGTACTCACTACGAAGACCCACGGGCGTATTACCGTATCGC aValTyrI ledrghspLyshrgPheGluTyrGlnGluIleArgGlnTyrSerLeuThrAsnGluProdsnGlyhrgTyrTyrArgIleAl $\begin{array}{lllllllllllllllllllllllllllllllll}V & Y & I & R & D & K & R & F & E & Y & Q & E & I & R & Q & Y & S & L & T & H & E & P & Y & G & R & Y & Y & R & I & A\end{array}$

901 GGTCAAACGGGAACGATGGGCAGCGTATCGGGCTATTTGCACGATGTCGCCCGCGAAGCGATGTGATTGAACTGGCCGCCCCGCACGG aValLysArgGluThrHetGlySerValSerGlyTyrLeuHishspValAlaArgGluGlyAspValIleGluleuAlaA laProHisGl

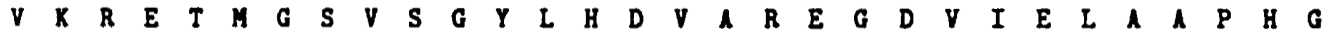

991 CGATTTCTACCTTGAGTCACGCCAGAGACGCCGTAGCGCTGATTTCCGCCGGTGTTGGTCAAACACCGATGCTCAGCATGCTGCACAG yAspPheT rrLeuGluValThrProGluThrProValA aleuIleSerAlaGl yValGlyGlnThrProletLeuSerHetLeuHisSe $\begin{array}{llllllllllllllllllllllllllllll}D & F & Y & L & E & V & T & P & E & T & P & V & A & L & I & S & A & G & V & G & Q & T & P & A & L & S & M & L & H & S\end{array}$

1081 CCTGAAAATCAGCAGCATCAGGCGGATATCTTCTGGTTACACGCGGCTGMAMCACAGAGTACATGCCTTCGCCGACGMATCGCCGA rLeuLyshsnGInGlnHisGInAlaAspIlePheTrpLeuHisAlaAlaGludsnThrGluValHisAlaPheAlahspGluIleAlads

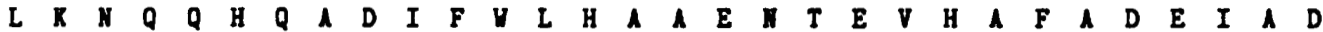

1171 TGTTGCCGCTACGCTGCCGCAGTTCCATCCTATGTCTGGTATCGGGAGCCTCATCGGMGCGGCACGTTCGGCGCATGCTTTTCACGG pValdlaAlaThrLeuProGInLeuGlnSerTfrValTrpTydrgGluAlaSerSerGluAlaAlabrgSerAl aHisAlaPheHisGl

$\begin{array}{llllllllllllllllllllllllllllll}V & A & A & T & L & P & Q & L & Q & S & Y & V & W & Y & R & E & A & S & S & E & A & A & R & S & A & H & A & F & H & G\end{array}$

1261 ATTGATGGCGTTGMGGACCTCCCGACGCCGTTCCGATGACAAACCTGCACTGTTATTTATGCGGCCCGGTCGCCTTATGCAATTCGC yLeuket A aLeulyshspLeuProThrProLeuProlfet ThrAsnLeuHisCysTyrLeuCysGlyProValAl aPheKetGInPheAl

L

1351 CGCCCGACAITGTTGGAGTTGGGATTACCGATCGCAGATTCATTACGAATGCTTTGGTCCGCACAGGTTATATACCGATAMAGG aAl aArgGInLeuLeuGluLeuGl JIleThrGluSerGlnIleHisTyrGluCysPhoGlyProHisLysValIle

$\begin{array}{lllllllllllllllllllllllll}A & R & Q & L & L & E & L & G & I & T & E & S & Q & I & H & Y & E & C & F & G & P & H & X & V & I\end{array}$

1441 TTATATTTATTCACACCAGCAGGCCGGGMTCCGGCTGTTTIATTTCCATTTATTTCCCAAAATAACACCAGTACAGAATACCT 1531 GACGAGGTACCGTIACTGTTTCGTATAGTTTCATTTACCACCGCGTCATGCTGACCAGTAMACACGCTCCCTCCCCCTTCTCATT

1621 TTTRATTCCCGATTGAMATAGTTMGTAMCCTTCATAMTMGAATAMMACACAATGTTACATTTMA

Fig. 2. For legend see facing page. 


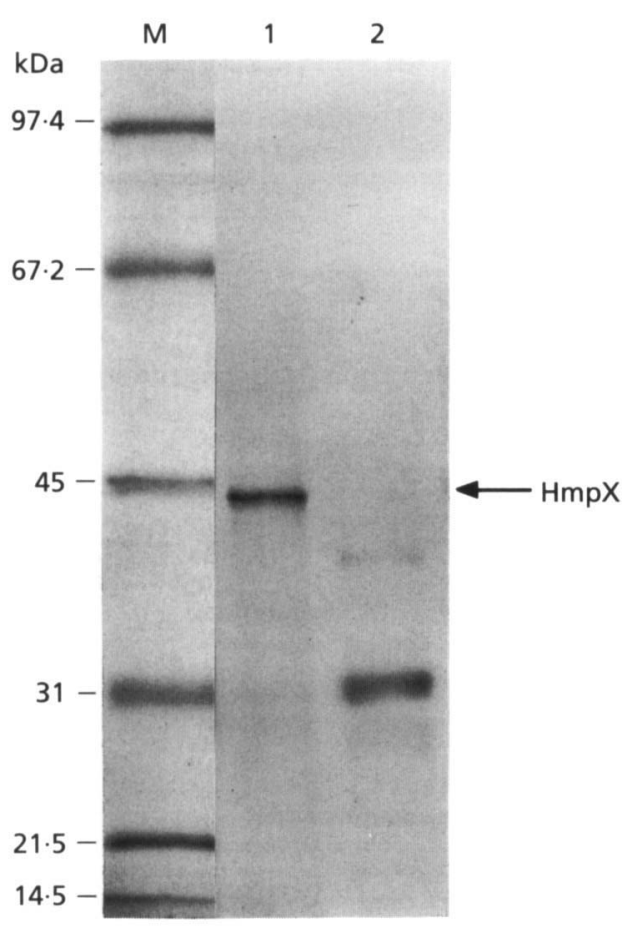

Fig. 3. Autoradiograms of ${ }^{35} \mathrm{~S}$-labelled proteins expressed in AR 1062 minicells containing plasmid p065 (lane 1) or vector alone (lane 2). Samples (10 $\mu \mathrm{g}$ protein in lanes 1 and 2$)$ were run on a $12 \%$ SDS-polyacrylamide gel. The HmpX protein is indicated by an arrow. Molecular mass standards (M) were stained with Coomassie blue.

typical signal peptide sequence was identified, suggesting that the protein is cytoplasmic.

\section{Identification of HmpX protein}

To identify the HmpX protein, plasmid p0165 was introduced into the minicell-producing strain $E$. coli AR 1062. Analysis of the ${ }^{35} \mathrm{~S}$-labelled products expressed from p0165 is shown in Fig. 3, lane 1. In addition to the pUCencoded polypeptides, mainly the $\beta$-lactamase, a polypeptide of apparent molecular mass $42 \mathrm{kDa}$ was produced.

\section{HmpX protein belongs to a family of flavohaemo- globins also present in $E$. coli and yeasts}

Screening of protein sequence databases revealed that the sequence of $\mathrm{HmpX}$ is highly similar to flavohaemoprotein (HMP) sequences. Over its whole sequence, HmpX showed $64 \%$ identity with E. coli Hmp (Vasudevan et al., 1991 ) and $36 \%$ identity with HMP from the yeasts Saccharomyces cerevisiae and Candida norvegiensis (Zhu \& Riggs, 1992; Iwaasa et al., 1992) (Fig. 4). HMPs from Alcaligenes eutrophus and Vibrio parabaemolyticus were recently found (respective accession numbers GenPept: AEFHPG and GenPept: VPU09005); these showed respectively $47 \%$ and $65 \%$ sequence identity with HmpX.

HMPs possess an $\mathrm{N}$-terminal domain similar to haemoglobins and a $\mathrm{C}$-terminal region similar to those of a family of reductases (Zhu \& Riggs, 1992; Andrews et al., 1992).

Amino acids 1 to 143 of $\mathrm{HmpX}$ show $45 \%$ identity with the complete amino acid sequence of the haemoglobin from the filamentous bacterium Vitreoscilla (Wakabayashi et al., 1986; Fig. 4). The similarity between the $\mathrm{N}$ terminal part of HmpX and plant leghaemoglobin or animal haemoglobin sequences was low but significant, ranging from 15 to $21 \%$ (over 150 amino acids). Comparison of protein sequences at the secondary structure level by HCA showed that HmpX possesses a globin fold and a conserved haem pocket (the HCA score of HmpX and human haemoglobin was as high as $76 \%$ ). HmpX possesses hydrophobic residues in 33 specific positions, which in globins form the conserved hydrophobic core described by Bashford et al. (1987). From the alignment of $\mathrm{HmpX}$ and globin sequences we also deduced that the distal and proximal haem ligands in HmpX could be the glutamine $\operatorname{Gln}^{53}$ in helix $\mathrm{E}$ and the histidine $\mathrm{His}^{84}$ in helix F, respectively. These residues are strictly conserved in the other HMPs and in Vitreoscilla haemoglobin (Perutz, 1986; Fig. 4). From these comparisons, we conclude that HmpX possesses a haemoglobin domain in its $\mathrm{N}$-terminal part. Furthermore, colonies of E. coli harbouring plasmid pB413 or p065 have a red coloration that could result from a large amount of haem in these cells.

In addition to its haemoglobin domain, $\mathrm{HmpX}$ possesses at its C-terminus (amino acids 150 to 395 ) a region having striking similarity with sequences of the ferredoxinNADP-reductase-like proteins (FenR-like proteins). These homologous proteins belong to a new flavoenzyme family (Karplus et al., 1991). Comparisons of $\mathrm{HmpX}$ with various members of this family showed that the sequence identity ranged from $15 \%$-with ferredoxin reductase (FenR) - to $24 \%$ with the nitrate reductases (NitR) and the NAD-cytochrome $b_{5}$ reductases (Cb5R, also called methaemoglobin reductase). The sequence identity with other oxido-reductase families was lower than $10 \%$. The atomic structure of the spinach FenR (Karplus et al., 1991) allowed the identification of the active-site residues, corresponding to the FAD- and NADP-binding sites. They are highly conserved in the FenR-like proteins (Karplus et al., 1991) and also in HmpX (Fig. 4). By similarity, we assume that $\mathrm{Arg}^{204}, \mathrm{Tyr}^{206}$, $\mathrm{Gly}^{227}, \mathrm{Ser}^{230}$ and $\mathrm{Phe}^{389}$ are involved in the FAD-binding of $\mathrm{HmpX}$. The $G x G x x P$ motif specific to the NAD(P)-binding site in FenR-like proteins is conserved in all the HMPs $\left({ }^{267}\right.$ GVGQTP ${ }^{272}$ in HmpX; see Fig. 4). Specific NADP-

Fig. 2. Nucleotide sequence of the $h m p X$ gene of $E$. chrysanthemi 3937, with the deduced amino acid sequence of HmpX The putative -35 and -10 regions and the Shine-Dalgarno sequence (SD) are indicated by dashed lines. The potential rho-independent termination sites are indicated by facing arrows underlining the inverted repeat of $\mathrm{G}+\mathrm{C}$-rich dyad symmetry preceding the poly(T) sequence. 
50
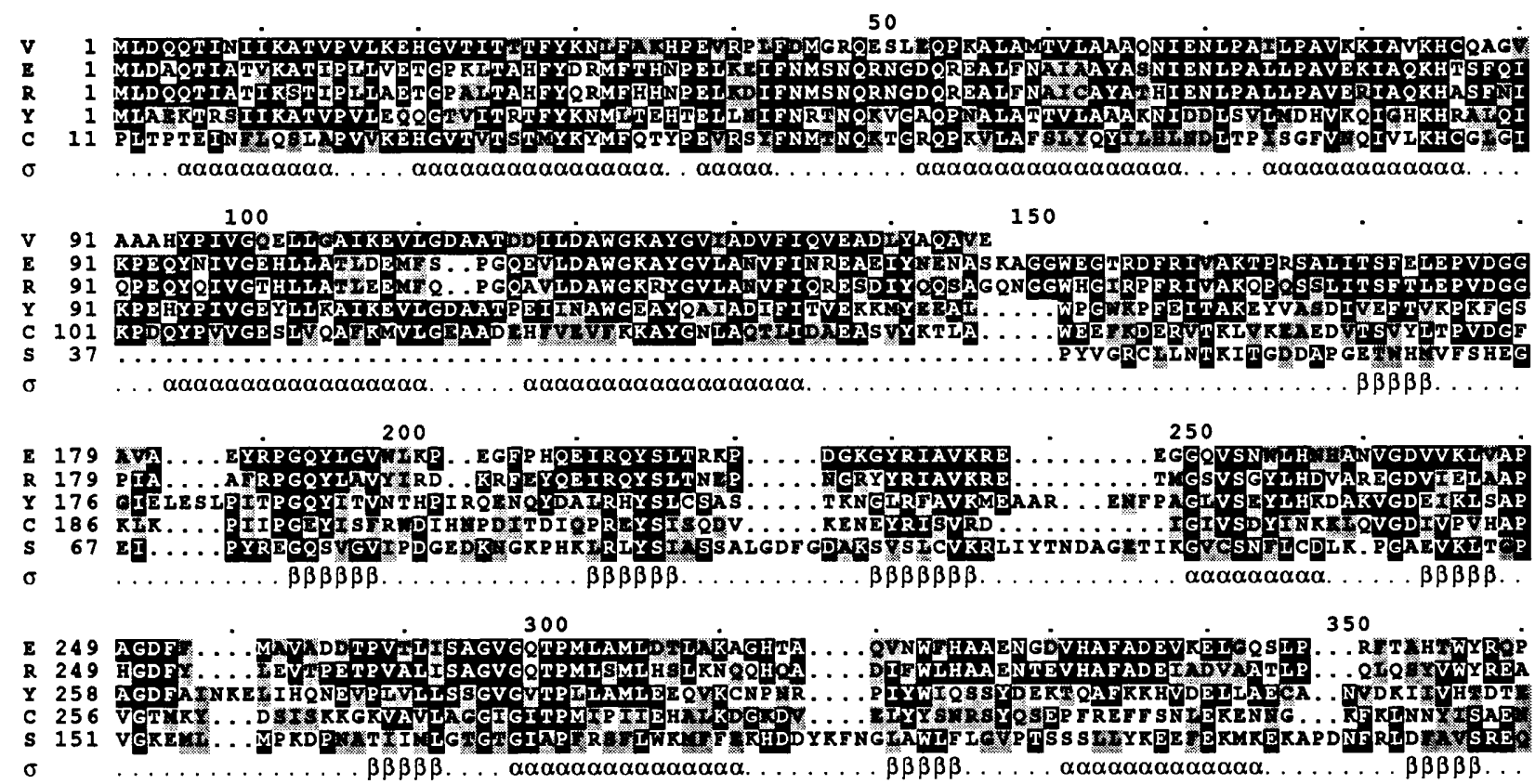

400

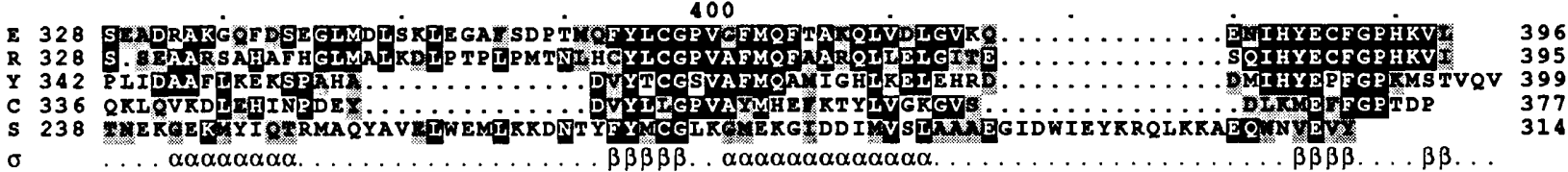

Fig. 4. Sequence alignment of Erwinia chrysanthemi $\mathrm{HmpX}$ and homologous proteins. The alignment of the sequences of Vitreoscilla haemoglobin (V). Escherichia coli Hmp (E), Erwinia chrysanthemi HmpX (R) Saccharomyces cerevisae Hmp (Y), Candida norvegiensis $\mathrm{Hmp}$ (C) and spinach ferredoxin reductase (S) is shown as deduced from HCA comparison. The oneletter amino acid code is used. Strictly conserved residues are indicated in black and conservatively changed residues in grey. Secondary structure elements are indicated under the alignments: $\alpha$ stands for $\alpha$-helix and $\beta$ for $\beta$-strand. The globin-like domain spans residues 1 to 143 and the FenR-like domain spans residues 150 to 395.

binding by bacterial HMP could be suggested from the conservation of $\operatorname{Arg}^{325}$. Despite the low sequence identity, the sequence alignment by the HCA method indicated that HmpX shares the specific structural features of the proteins from this new family of reductases. The HCA score of the alignment of $\mathrm{HmpX}$ and FenR was as high as $76.5 \%$. We conclude that these proteins possess a similar fold.

The Hmp protein of E. coli (Vasudevan et al., 1991) has been shown to be associated with a dihydropteridine reductase activity (DHPR). However, no increase in DHPR activity could be demonstrated in E. coli harbouring $\mathrm{pB} 413$, and no difference in DHPR activity could be found between E. chrysanthemi 3937 and an $\mathrm{HmpX}^{-}$ mutant (PMV4125).

\section{Role of HmpX in PL production}

Since oxygen may play a role in soft rot disease (De Boer \& Kelman, 1978) and HmpX possesses the structural features of a haemoglobin, we studied the effect of an $b m p X$ mutation on PL production in aerobic or in microaerobic conditions. Bacteria were grown in minimal medium with glycerol. When we measured PL activity in the culture medium under aerobic conditions, no dif-
Table 2. PL specific activity in 3937 (wild-type) and hmpX mutant strains

Strains were grown in M9 medium supplemented with $0.5 \%$ glycerol. Specific activity is expressed as $\mu \mathrm{mol}$ unsaturated products liberated $\min ^{-1}(\mathrm{mg} \text { bacterial dry weight })^{-1}$. The experiments were carried out at least three times. The values obtained for a typical experiment are given. ND, Not determined.

\begin{tabular}{|lccc|}
\hline \multirow{2}{*}{ Strain } & \multicolumn{3}{c|}{ PL specific activity } \\
\cline { 2 - 4 } & Aerobic & Microaerobic & In planta* \\
\hline 3937 & $0 \cdot 1$ & 5 & 30 \\
PMV4125 & $0 \cdot 1$ & $0 \cdot 4$ & ND \\
\hline
\end{tabular}

* Bacterial numbers were determined by dilution plating $\left(3937: 10^{9}\right.$ c.f.u. $\mathrm{ml}^{-1}$; PMV4125: $<10^{7}$ c.f.u. $\mathrm{ml}^{-1}$ ).

ference was observed between E. chrysanthemi strains 3937 (wild-type) and PMV4125 $\left(\mathrm{HmpX}^{-}\right)$. In microaerobic conditions, however, PL activity in strain 3937 was 50 fold higher than in aerobic conditions, whereas in the $\mathrm{HmpX}^{-}$strain it was only four- to fivefold higher (Table 2 ). The same results were observed when cell lysates were 
assayed for PL activity, suggesting that PL production and not secretion was affected (data not shown). In addition, the $\mathrm{HmpX}^{-}$mutant grew similarly to the wildtype strain in aerobic and in microaerobic conditions.

We next studied the effect of $b m p X$ mutation on PL synthesis in planta. Isolated Saintpaulia leaves were infiltrated with strain 3937 or PMV4125; the intercellular fluid was recovered after $24 \mathrm{~h}$ and PL activity measured. The wild-type strain exhibited a 300 -fold increase in PL production $\left(10^{9}\right.$ c.f.u. $\left.\mathrm{ml}^{-1}\right)$ (Table 2). PMV4125 did not grow in planta $\left(5 \times 10^{6}\right.$ c.f.u. $\left.\mathrm{ml}^{-1}\right)$. To confirm the role of the $b m p X$ mutation, plasmid p 0165 harbouring the $b m p X$ gene was introduced into PMV4125, and PL synthesis was measured in bacteria infiltrated into Saintpaulia leaf tissue: wild-type levels of PL synthesis and maceration were observed. These results, showing the interrelation between PL synthesis and HmpX expression, shed light on the reduced pathogenicity of HmpX mutants observed on Saintpaulia plants.

\section{HmpX expression in coculture with tobacco cells}

As HmpX mutants were unable to grow in planta, we used co-culture with tobacco cells to study the effect of a plant environment on the transcription of $h m p X$. When grown in $\mathrm{M} 9$ minimal medium, strains $\mathrm{X} 2$ and $\mathrm{X} 8$ showed no difference in Gus activity ( 6 a.u.). However, when these strains were grown in co-culture with tobacco cells we found a 60 -fold increase in gus expression after $20 \mathrm{~h}$ for strain X8 (370 a.u.) but no increase (7 a.u.) for X2, which possesses an insertion in the reverse orientation. These results might suggest that $b m p X$ is induced by factor(s) released by the infected plant.

\section{Conclusions}

In this paper we have presented the sequence of the $b m p X$ gene of E. chrysantbemi and analysed that of its corresponding protein. HmpX belongs to a family of proteins which possess two distinct regions, a haemoglobin domain in their $\mathrm{N}$-terminal part and a flavin-containing reductase region in their $\mathrm{C}$-terminal part.

We have shown that HmpX protein is essential for $E$. chrysantbemi pathogenicity on Saintpaulia plants and that mutation in this gene affects the survival of the bacteria in planta. In addition, when bacteria harbouring a $b m p X:: g u s$ fusion were co-cultivated with tobacco cells, a strong increase in Gus activity was observed, suggesting that $b m p X$ is induced in planta. However, no $b m p X$ induction was observed in microaerobic conditions, suggesting that its activation is induced by both plant factors and environmental conditions. Interestingly, sequencing of the upstream region of the pel $A$ gene of $E$. chrysanthem $i$ strain EC16 (Tamaki et al., 1988) showed that in this strain, the $b m p X$ gene is partially deleted. The remaining two short segments of the $\mathrm{N}$ - and C-terminal domains of HmpX lack the active-site regions (Andrews et al., 1992). It is notable that the pathogenicity of strain EC16 on several hosts is severely reduced (M. Boccara, unpub- lished results). Although this strain possesses several deletions in its genome, it is tempting to correlate the deletion in $b m p X$ and the loss of pathogenicity.

In microaerobic conditions, in the absence of $\mathrm{HmpX}$, the level of PL activity is very low. Using pel: :gus fusions we found that the $b m p X$ mutation affected PL synthesis at the transcriptional level (M. Boccara, data not shown). Reduced PL activity in an $\mathrm{HmpX}^{-}$mutant would result in a reduced pathogenicity. As we have shown that $b m p X$ mutants are non-pathogenic, these results might suggest that in the plant intercellular fluid, oxygen is not available for E. chrysanthemi.

What function can be attributed to HmpX? A similar protein, $\mathrm{Hmp}$, has been isolated in Escherichia coli based on its DHPR activity. Recently, a ferrisiderophore reductase activity has also been found associated with E. coli Hmp (Andrews et al., 1992). A ferrisiderophore reductase activity for HmpX is an attractive hypothesis as it has been shown that an iron assimilation system is necessary for E. chrysanthemi pathogenicity (Enard et al., 1988). However, the reductase activities associated with E. coli Hmp have different substrate specificities, which could suggest that the reductase activity of Hmp assayed in aerobic conditions is not highly specific. Furthermore, the major DHPR activity in E. coli is associated with a protein which does not contain a haemoglobin domain (Vasudevan et al., 1988) and no haem domain is required for the ferrisiderophore reductase activity (Fontecave et al., 1987; Andrews et al., 1992). We found no DHPR activity associated with $\mathrm{HmpX}$ in crude bacterial extracts. As multiple ferrisiderophore reductase activities are supposed to be present in E. chrysanthemi as in E. coli, the purification of HmpX should help to determine its function and confirm the presence of the predicted domains of this protein. Recently, we showed that the purified haemoglobin domain binds haem and that the holo-haemoglobin domain possesses a visible absorption spectra similar to human haemoglobin spectra (G. Labesse, unpublished results).

An alternative function can be hypothesized from the sequence comparisons. Vitreoscilla, a bacterium living in low-oxygen environments, produces a haemoglobin, $\mathrm{VtHb}$ (Wakabayashi et al., 1986), and an associated reductase has been recently purified (Jakob et al., 1992). $\mathrm{VtHb}$ is similar to the $\mathrm{N}$-terminal region of $\mathrm{HmpX}$, and the NAD-methaemoglobin reductase possesses properties very similar to the family of reductases homologous to the C-terminal domain of $\mathrm{HmpX}$. VtHb is auto-oxidizable, and the methaemoglobin reductase keeps $\mathrm{VtHb}$ physiologically functional. Similarly, mammal Cb5R (also named methaemoglobin reductase) reduces the oxidized haem and, among the FenR-like proteins, is the most similar to HmpX. It has also been suggested that the Vitreosilla haemoglobin might function as a terminal oxidase in oxygen-limiting conditions (Dikshit et al., 1992). By analogy, HmpX could be a haemoglobin plus a NADPmethaemoglobin reductase on a single polypeptide chain. Its function could be to provide, shortly after infection, a new electron pathway to the bacterium in the unfavour- 
able plant environment. As plants are known to generate oxygen radicals after microbial infections (for a review see Sutherland, 1991), it could be suggested that the reductase activity of HmpX recycles the auto-oxidizable haemoglobin of $\mathrm{HmpX}$. To test this hypothesis, the purification of $\mathrm{HmpX}$ is under way.

\section{ACKNOWLEDGEMENTS}

We thank J. Chomilier for critical reading of our manuscript, M. A. Barny for helpful discussions, A. Kotoujansky for help in $b m p X$ sequencing, and D. Expert and R. Labbe for pointing out interesting references. This work was supported by the INRA. S. Favey and G. Labesse are fellows from the Ministère de l'Enseignement Superieur et de la Recherche.

\section{REFERENCES}

Altschul, S. F., Gish, W., Miller, W., Myers, E. W. \& Lipman, D. J. (1990). Basic local alignment search tool. J Mol Biol 215, 403-410.

Andrews, S. C., Shipley, D., Keen, J. N., Findley, J. B. C., Harrison, P. M. \& Guest, J. R. (1992). The hemoglobin-like protein (HMP) of Escherichia coli has ferrisiderophore reductase activity and its Cterminal domain shares homology with ferredoxin $\mathrm{NADP}^{+}$reductase. FEBS Lett 32, 247-252.

Ausubel, F. M., Brent, R., Kingston, R. E., Moore, D. D., Seidman, J. G., Smith, J. A. \& Struhl, K. (1987). Current Protocols in Molecular Biology. New York: Greene Publishing and Wiley-Interscience.

Bardonnet, N. \& Blanco, C. (1992). uid $A$ antibiotic resistance cassettes for insertion mutagenesis, gene fusion and genetic constructions. FEMS Microbiol Lett 93, 243-248.

Bashford, D., Chothia, C. \& Lesk, A. M. (1987). Determinants of a protein fold. Unique features of globin amino acid sequences. $J \mathrm{Mol}$ Biol 196, 199-216.

Bauer, D. W., Bogdanove, A. J., Beer, V. S. \& Collmer, A. (1994). Erwinia cbrysanthemi brp genes and their involvement in soft rot pathogenesis and elicitation of the hypersensitive response. Mol Plant-Microbe Interact 5, 573-581.

Beaulieu, C., Boccara, M. \& Van Gijsegem, F. (1993). Pathogenic behaviour of pectinase-defective Erwinia chrysanthemi mutants on different plants. Mol Plant-Microbe Interact 6, 197-202.

Bertheau, Y., Madgidi-Hervan, E., Kotoujansky, A., Nguyen-The, C., Andro, T. \& Coleno, A. (1984). Detection of depolymerase isoenzymes after electrophoresis or electrofocusing, or in titration curves. Anal Biochem 139, 383-389.

Billing, E. (1987). Bacteria as plant pathogens. Aspects Microbiol 14, 34-49.

Boccara, M., Diolez, A., Rouve, M. \& Kotoujansky, A. (1988). The role of individual pectate lyases of Erwinia cbrysanthemi strain 3937 in pathogenicity on Saintpaulia plants. Physiol Mol Plant Patbol 33, 95-104.

Castilho, B. A., Olfson, P. \& Casadaban, M. J. (1984). Plasmid insertion mutagenesis and lac gene fusion with mini-Mu bacteriophage transposons. J Bacteriol 158, 488-495.

Dayhoff, M. O., Schwartz, R. M. \& Orcutt, B. C. (1978). A model of evolutionary change in proteins. Atlas Protein Sequence Struct 3, 345-352.

De Boer, S. H. \& Kelman, A. (1978). Influence of oxygen concentration and storage factors on susceptibility of potato tuber to bacterial soft rot (Erwinia carotovora). Potato Res 21, 65-80.
Devereux, J., Haeberli, P. \& Smithies, O. (1984). A comprehensive set of sequence analysis programs for the VAX. Nucleic Acids Res 12, 387-395.

De Witt, P. \& Spikman, G. (1982). Evidence for the occurrence of race and cultivar-specific elicitors of necrosis in intracellular fluids of compatible interactions of Cladosporium fulvum (Syn. Fulvia fulva) and tomato. Physiol Plant Pathol 24, 17-23.

Dikshit, R. P., Dikshit, K. L., Liu, Y. \& Webster, D. A. (1992). The bacterial hemoglobin from Vitreoscilla can support the aerobic growth of Escherichia coli lacking terminal oxidases. Arch Biocbem Biophys 292, 29-33.

Enard, C., Diolez, A. \& Expert, D. (1988). Systemic pathogenicity of Erwinia chrysantbemi 3937 requires a functional iron assimilation system. J Bacteriol 170, 2419-2426.

Expert, D. \& Gill, P. R. (1992). Iron: a modulator in bacterial pathogenicity and symbiotic nitrogen-fixation. In Molecular Signals in Plant-Microbe Communications, pp. 229-245. Edited by D. P. Verma. Boca Raton, FL: CRC Press.

Fontecave, M., Eliasson, R. \& Reichard, P. (1987). NAD(P)H: flavin oxidoreductase of $E$. coli. A ferric iron reductase participating in the generation of the free radicals of ribonucleotide reductase. $J$ Biol Chem 262, 12325-12331.

Gaboriaud, C., Bissery, V., Benchetrit, T. \& Mornon, J.-P. (1987). Hydrophobic cluster analysis: an efficient way to compare and analyse amino acid sequences. FEBS Lett 224, 149-155.

Gregorini, G. \& Laloue, M. (1980). Biological effects of cytokinin antagonists 7-(pentylamino) and 7-(benzylamino)-3-methylpyrazolo (4,3-d) pyridines on suspension-cultured tobacco cells. Plant Pbysiol 65, 363-367.

Iwaasa, H., Takagi, T. \& Shikama, K. (1992). Amino acid sequence of yeast hemoglobin: a two domain structure. J Mol Biol 227, 948-954.

Jakob, W., Dale, A. W. \& Kroneck, M. H. (1992). NADH-dependent methemoglobin reductase from the obligate aerobe Vitreosilla: improved method of purification and reexamination of prosthetic groups. Arch Biochem Biopbys 292, 29-33.

Karplus, P. A., Daniels, M. J. \& Herriott, J. R. (1991). Atomic structure of ferredoxin-NADP ${ }^{+}$reductase: prototype for a structurally novel flavoenzyme family. Science 251, 60-66.

Kotoujansky, A., Diolez, A., Boccara, M., Bertheau, Y., Andro, T. \& Coleno, A. (1985). Molecular cloning of Erwinia chrysanthemi pectinase and cellulase structural genes. EMBO J 4, 781-785.

Maniatis, T., Fritsch, E. F. \& Sambrook, J. (1982). Molecular Cloning: a Laboratory Manual. Cold Spring Harbor, NY: Cold Spring Harbor Laboratory.

Miller, J. H. (1972). Experiments in Molecular Genetics. Cold Spring Harbor, NY: Cold Spring Harbor Laboratory.

Moran, F., Nasumo, S. \& Starr, M. P. (1968). Extracellular and intracellular polygalacturonic acid trans-eliminases of Erwinia carotovora. Arch Biochem Biophys 123, 298-306.

Murphy, G. \& Kavanagh, T (1988). Speeding-up the sequencing of double stranded DNA. Nucleic Acids Res 16, 5198.

Pearson, W. R. \& Lipman, D. (1988). Improved tools for biological sequence comparison. Proc Natl Acad Sci US A 85, 2444-2448.

Perutz, M. F. (1986). A bacterial haemoglobin. Nature 322, 405.

Rambach, A. \& Hogness, D. S. (1977). Translation of Drosophila melanogaster sequences in Escherichia coli. Proc Natl Acad Sci US A 74, 5041-5045.

Reverchon, S., Van Gisjegem, F., Rouve, M., Kotoujansky, A. \& Robert-Baudouy, J. (1986). Organisation of a pectate lyase gene family in Erwinia chrysanthemi. Gene 49, 215-224. 
Reyes, O., Beyou, A., Mignotte-Vieux, C. \& Richaud, F. (1987). MiniMu transduction: cis-inhibition of Mud transposons. Plasmid 18, 183-192.

Risler, J. L., Delorme, M. O., Delacroix, H. \& Henaut, A. (1988). Amino acid substitutions in structurally related proteins. A pattern recognition approach. $J$ Mol Biol 204, 1019-1029.

Roeder, D. L. \& Collmer, A. (1985). Marker-exchange mutagenesis of a pectate lyase isozyme gene in Erwinia chrysanthemi. J Bacteriol 164, 51-56.

Sanger, F., Nicklen, S. \& Coulson, A. R. (1977). DNA sequencing with chain-terminating inhibitors. Proc Natl Acad Sci USA 74, 5463-5467.

Sutherland, M. W. (1991). The generation of oxygen radicals during host plant responses to infection. Physiol Mol Plant Pathol 39, 79-95.

Tamaki, S. G., Shaw, D. C., Robeson, M., Manulis, S. \& Keen, N. T. (1988). Structure and organisation of the pel genes from Erwinia chrysanthemi EC16. J Bacteriol 170, 3468-3478.

Van Gijsegem, F., Gelin, S. \& Boucher, C. (1993). Conservation of secretion pathways for pathogenicity determinants of plant and animal bacteria. Trends Microbiol 1, 175-180.
Vasudevan, S. G., Shaw, D. C. \& Armarego, W. L. F. (1988). Dihydropteridine reductase from Eschericbia coli. Biochem $J$ 255, 581-588.

Vasudevan, S. G., Armarego, W. L. F., Shaw, D. C., Lilley, P. E., Dixon, N. E. \& Poole, R. K. (1991). Isolation and nucleotide sequence of the $h m p$ gene that encodes a hemoglobin-like protein in Escherichia coli K12. Mol \& Gen Genet 226, 49-58.

Wakabayashi, S., Matsubara, H. \& Webster, D. A. (1986). Primary sequence of a dimeric bacterial haemoglobin from Vitreoscilla. Nature 322, 481-483.

Willis, D. K., Rich, J. J. \& Hrabak, E. M. (1991). brp genes of phytopathogenic bacteria. Mol Plant-Microbe Interact 4, 132-138.

Woodcock, S., Mornon, J. P. \& Henrissat, B. (1992). Detection of secondary structure elements in proteins by hydrophobic cluster analysis. Protein Eng 5, 629-635.

Zhu, H. \& Riggs, A. F. (1992). Yeast flavohemoglobin is an ancient protein related to globins and a reductase family. Proc Natl Acad S $i$ US A 89, 5015-5019.

Received 1 September 1994; revised 26 October 1994; accepted 7 November 1994. 